\title{
A rapid procedure for extracting genomic DNA from leukocytes
}

\author{
S.W.M.John, G.Weitzner, R.Rozen and C.R.Scriver \\ Departments of Pediatrics and Biology, Centre for Human Genetics, McGill University-Montreal \\ Children's Hospital Research Institute, Montreal, Quebec, Canada
}

Submitted November 27, 1990

We have developed a rapid procedure, based on standard protocols, to isolate DNA from leukocytes. The procedure yields $100 \mu \mathrm{g}$ to $150 \mu \mathrm{g}$ from $5 \mathrm{ml}$ of blood. The DNA produced is of good quality (Fig. 1) and is suitable for restriction enzyme digestion or PCR amplification.

\section{METHOD}

Conduct all steps at room temperature unless otherwise stated.

1. Collect $5 \mathrm{ml}$ of blood in a vacutainer tube (Becton Dickinson) containing EDTA and mix.

2. Make volume up to $10 \mathrm{ml}$ with solution $1(10 \mathrm{mM}$ Tris $\mathrm{pH}$ 7.6; $10 \mathrm{mM} \mathrm{KCl} ; 10 \mathrm{mM} \mathrm{MgCl}$ ).

3. Add $120 \mu \mathrm{l}$ Nonidet $\mathbf{P} 40$ (BDH) to lyse the cells. Mix well by inverting several times.

4. Spin down the nuclear pellet at $2000 \mathrm{rpm}$ for $10 \mathrm{mins}$.

5. Pour off the supernatant without dislodging the pellet. The pellets can be stored frozen.

6. Gently resuspend pellet well in $800 \mu \mathrm{l}$ of solution $2(10 \mathrm{mM}$ Tris pH 7.6; $10 \mathrm{mM} \mathrm{KCl} ; 10 \mathrm{mM} \mathrm{MgCl} ; 0.5 \mathrm{M} \mathrm{NaCl} ; 0.5 \%$ SDS; 2 mM EDTA). Solution 2 will lyse the nuclei so be careful not to shear the DNA. Transfer to a $1.5 \mathrm{ml}$ microcentrifuge tube.

7. Add $400 \mu$ l of distilled phenol (saturated with $1 \mathrm{M}$ Tris $\mathrm{pH}$ 8.0) and mix well.

8. Microfuge for $1 \mathrm{~min}$ at $12000 \mathrm{rpm}$. Transfer upper phase to a clean microfuge tube. Do not worry about transferring a little of the interface.

9. Add $200 \mu \mathrm{l}$ of phenol and $200 \mu \mathrm{l}$ of chloroform:isoamyl alcohol (24:1). Mix well by inverting.

10. Spin for $1 \mathrm{~min}$ at $12000 \mathrm{rpm}$. Transfer upper phase to a clean microfuge tube.

11. Add $700 \mu \mathrm{l}$ of chloroform:isoamyl alcohol and extract as above.

12. Transfer upper aqueous phase to a small clean container. Avoid removing the interface. Add 2 volumes of ice cold ethanol and mix to precipitate the DNA*.

13. With the sealed tip of a pasture pipette, transfer the DNA fibres to a microcentrifuge tube containing $1 \mathrm{ml}$ of $70 \%$ ethanol. Mix well to wash the DNA.

14. Spin for 5 mins at full speed. Discard the ethanol and dry pellet in a speed vac. Resuspend DNA in sterile water at $65^{\circ} \mathrm{C}$. Do not over-dry genomic DNA or it will be difficult to resuspend.

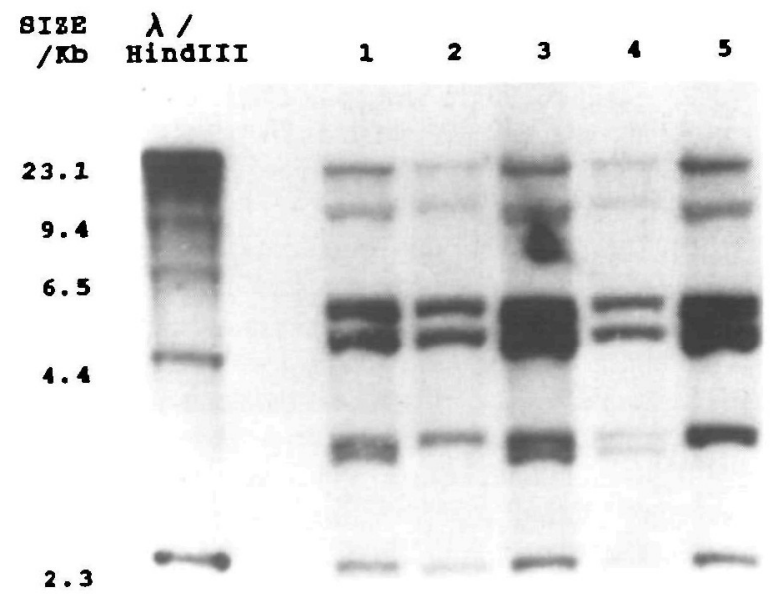

Figure 1. Southern analysis. DNA samples were digested with HindIII, electrophoresed and blotted onto a nitrocellulose membrane and hybridized with a full-length radiolabelled phenylalanine hydroxylase (PAH) CDNA probe. Lanes 1,2 and 3 contain DNA isolated by standard procedures while lanes 4 and 5 contain DNA isolated with this protocol. The DNA in all lanes appears to be of similar quality.

*If the blood is old (1 week or so) very little DNA may precipitate out. If so, proceed as follows:

Place sample at $-20^{\circ} \mathrm{C}$ overnight. Transfer $1.5 \mathrm{ml}$ to a microcentrifuge tube and spin for 10 mins at full speed. Discard the ethanol and add the remainder of the sample. Spin as above. Discard the ethanol. Wash the pellet in $70 \%$ ethanol and continue as in step 14 .

\section{ACKNOWLEDGEMENTS}

Dr Savio Woo for PAH cDNA. The Thomas and Elizabeth Williams Scholarship, Montreal Children's Hospital Research Institute Studentship, FRSQ and MRC for support. Colleagues for testing the protocol. 